\title{
Flood sensitivity of the Bavarian Alpine Foreland since the late Middle Ages in the context of internal and external climate forcing factors
}

\author{
O. Böhm ${ }^{1}$, J. Jacobeit ${ }^{1}$, R. Glaser ${ }^{2}$, and K.-F. Wetzel ${ }^{1}$ \\ ${ }^{1}$ Institute of Geography, University of Augsburg, Augsburg, Germany \\ ${ }^{2}$ Institute of Geography, Albert-Ludwigs-Universität Freiburg, Freiburg, Germany \\ Correspondence to: O. Böhm (oliver.boehm@geo.uni-augsburg.de)
}

Received: 28 May 2014 - Published in Hydrol. Earth Syst. Sci. Discuss.: 3 July 2014

Revised: 27 October 2015 - Accepted: 28 October 2015 - Published: 3 December 2015

\begin{abstract}
This paper describes the flood sensitivity of the Bavarian part of the Alpine Foreland of Germany and addresses different questions concerning climate variability and flood frequencies, from the 14th century until today. The focal point of the paper is the flood frequency of the superordinate spatial unit of the Bavarian Foreland. Based on written historical sources, the flood history of the Alpine Foreland of Germany can be reconstructed back to the 14th century. One major result is the occurrence of "flood-rich" and "floodpoor" episodes in almost cyclical sequences. Flood-rich periods, before the 16th century based on limited available data, were recorded in the periods 1300-1335, 1370-1450, 14701525, 1555-1590, 1615-1665, 1730-1780, 1820-1870, and 1910-1955 as well as in a ninth period beginning in 1980 . The flood-rich periods are characterized by longer flood duration. Most of the flood-rich and flood-poor periods (in particular the beginning and the end of them) can be connected to changes in natural climate variability. These include changing sunspot numbers (as a measure of solar activity), so-called Little Ice Age type events (LIATEs) as well as changes in the North Atlantic Oscillation (NAO). Climate signals from external forcing factors, which could be used to explain the changing flood frequencies in the Bavarian Alpine Foreland, end in 1930. Relationships within the climate system such as the correlation of flood frequencies with the NAO have changed during the transition from the post Little Ice Age period to the Modern Climate Optimum around 1930. Natural climate variability might have been overlaid by anthropogenic climate change.
\end{abstract}

\section{Introduction}

Historical climatology, especially the branch addressing historical floods, has gained increasing interest during the recent decades. Different parts of central Europe have been investigated: Schmoecker-Fackel and Naef (2010), Pfister (1984, 1996, 1999) and Wetter et al. (2010) analyzed the flood history of Switzerland; Brázdil et al. (2005) examined the flood history of the Czech Republic; Böhm and Wetzel (2006), Mudelsee et al. (2004), Deutsch and Pörtge (2001, 2002), Deutsch et al. (2004) and Glaser (2008) investigated different parts or catchments in Germany; Rohr $(2008,2013)$ examined extreme natural events in Austria; Sturm et al. (2001) and Glaser and Stangl (2003a, b) analyzed central European flood histories; and Kiss and Laszlovszky (2013) examined parts of the Danube for the western and central Carpathian Basin.

Nevertheless, the flood history of the entire Bavarian Alpine Foreland has not been systematically analyzed until now (cf. Böhm, 2011). Additionally, the Bavarian Alpine Foreland represents a region with a high susceptibility to climatic change (cf. Auer et al., 2007). The Bavarian part of the Alpine Foreland of Germany (hereafter termed Bavarian Foreland) has experienced flood events on a regular basis, but the return periods, e.g., for floods as well as for floodrich or flood-poor periods, cannot be derived from a standard 30-year reference period. All major summer floods have been triggered by cyclones following a special pathway (cf. van Bebber, 1891). This so-called Vb cyclone track seems to be the main precondition causing catastrophic flood events in the Bavarian Foreland, currently and also in the past (yet 
not every $\mathrm{Vb}$ cyclone affects the whole investigation area). Reconstructions of historic weather patterns show the appearance of this phenomenon in the past (cf. Böhm, 2011). The recent period, starting in 1997, has experienced numerous floods triggered by $\mathrm{Vb}$ conditions during the summer months. The so-called "(river) Oder Flood 1997" and the "Pfingsthochwasser (Whitsun Flood) 1999", both of which took place at the end of May, can be compared to the following summer floods of 2002 (Elbe/Danube floods) and 2005 (Alps Flood). All of these floods (despite their special naming) have affected the Bavarian Foreland.

Will recent climatic change modify the flood frequencies within the Bavarian Alpine Foreland or have the flood frequencies varied due to altering climatic conditions since historical times? In the context of recent discussions of whether man-made climate change will modify the present state of flood frequencies, a look back into the past is essential to understand the occurrence of floods in general and of recent floods in particular. In order to understand climatic variability and changes in a comprehensive way, it is necessary to review long time series. A perceived increase of summer floods in eastern Germany and Bavaria since 1997 requires examination of long time series to estimate changes in flood frequencies in a proper way. In view of the annual distribution of flood events within the Alpine Foreland of Germany, summer floods prove to be the most important.

To generate long time series, it was necessary to integrate three different periods of flood documentation. The oldest pieces of information originate from the so-called period of documentary evidence and have been obtained from historical recordings such as chronicles and compilations from the late Middle Ages. These written records can be statistically analyzed, as depicted in Glaser (2008). From the year 1826 onward, data are available from the so-called early instrumental period (EIP; cf. Jacobeit et al., 1998). At least one representative gauging station in the lower sections of every Alpine river recorded historic water levels which can be evaluated. From the beginning of the 20th century until now, modern instrumental data (water level and discharge measurements) are available. The separately evaluated flood histories of the rivers Iller, Lech with tributary Wertach, Isar, Inn and its tributary Salzach have been merged to form one overall time series. The merging of the single time series should reveal the flood susceptibility of a superordinate spatial unit based on recent administrative borders with consideration to climatic parameters. In the Methods section, the merging of the single time series is more elaborately described. Single flood events as well as quantification of flood events do not stand in the limelight of the current paper. The time line of the flood history of the Bavarian Foreland includes 584 individual flood events (see Methods section).

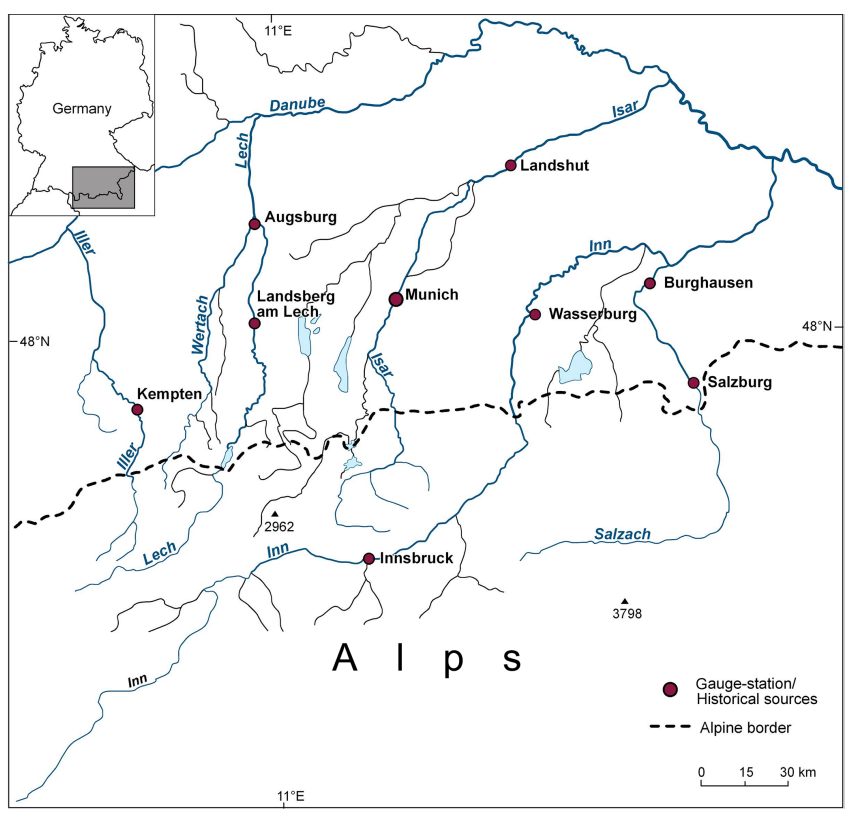

Figure 1. The investigation area Bavarian Foreland is bordered by the rivers Iller, Danube, Inn/Salzach and the Alpine border (dashed line). Red spots indicate outstanding historical locations and gauges.

\section{Investigation area}

In this paper the Bavarian Foreland is defined by the lower sections of the catchment areas of the aforementioned rivers, from west to east the research area is bordered by the river Iller in the west and the rivers Inn and Salzach in the east, as depicted in Fig. 1. The headwaters, however, are located in the Alps so that all of the rivers are northern Alpine mountain rivers (except the river Wertach which should be regarded as a foreland river). The main rivers Iller, Lech, Isar and Inn are Alpine tributaries of the Danube river.

All of the rivers coming from the Northern Limestone Alps traverse the flysch zone, enter the area of the faulted molasse sediments and cross the belt of Pleistocene moraines and gravel fields. The substratum of the lower river sections is formed of sandy sediments of the molasse trough. All traversed geological formations differ in their east-to-west extension. The geological formations of the outer-Alpine stream segments are of particular interest because of their texture. Due to the texture of the subsoil and anthropogenic encroachments from 1850 on, the riverbeds have become deeper. In about 1850 the Bavarian Administration systematically started riverbed corrections in order to prevent floods, to protect infrastructure like railways and roads and to support agriculture in the fertile plains and meadows supplying the growing population. In Fig. 2a one can see the beginning of anthropogenic encroachments impacting on river flow through the gauged measurements, starting at around 1860. The gauges' neutral points have not been changed, staff 

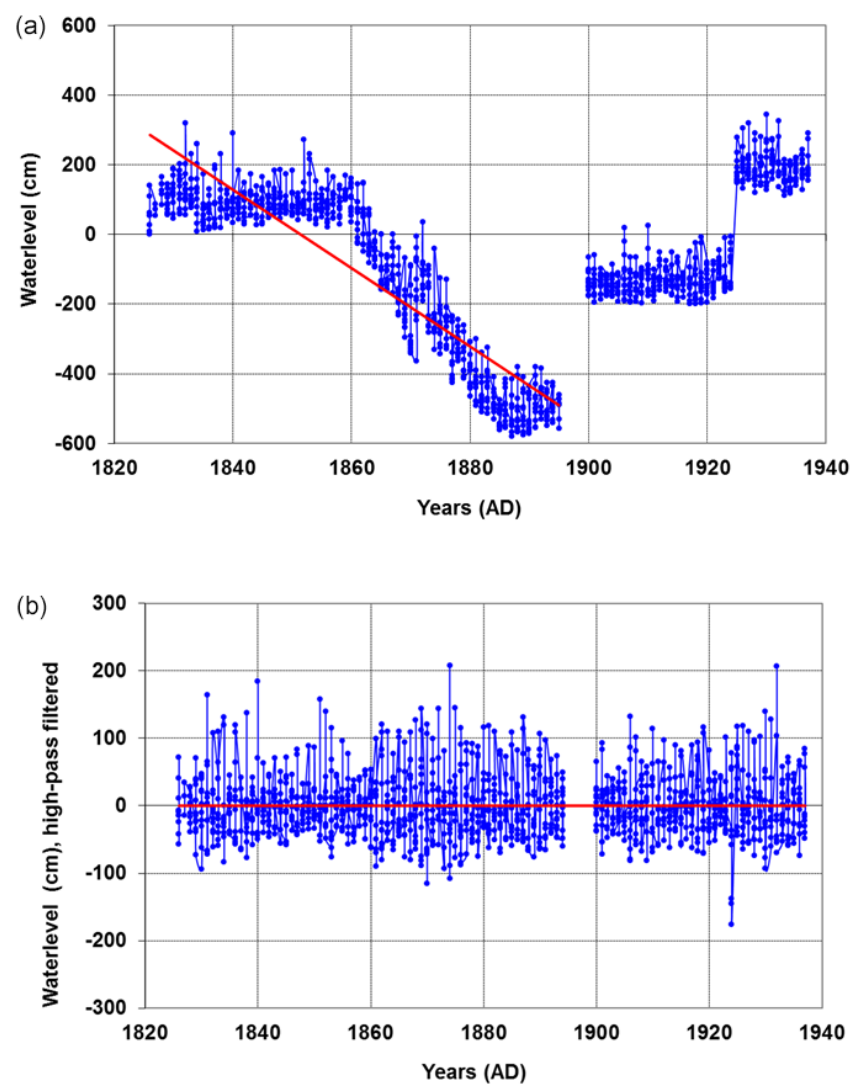

Figure 2. (a), (b): monthly maxima of water level (in $\mathrm{cm}$ ) from 1826 to 1937 at the gauge Ettringen/Wertach (35 km south of Augsburg). (a) original data from official records and (b) high-passfiltered data

gauges have been prolonged into the negative measurement range. These circumstances affect hydrological interpretations concerning the EIP. To assure homogeneity in comparison of flood events of individual time series, a high-pass filter has been applied (see Methods). The regional distribution of annual precipitation varies from around $600 \mathrm{~mm} \mathrm{a}^{-1}$ in the region of the Danube river to $2500 \mathrm{~mm} \mathrm{a}^{-1}$ and more within the high-elevation areas. The share of Alpine catchment is important for the runoff of the headwaters into the Bavarian Foreland due to its function as a temporary water storage reservoir and orographic barrier. In Table 1 the reference data of the relevant rivers are listed.

In the Bavarian Foreland we can differentiate spatial and chronological aspects of flood genesis as a function of hypsometric distribution and thereto linked the snow retention to the individual catchments. We can observe a west-toeast gradient contrasting the chronological annual mean discharge maximum starting in the western part with the investigation area with a spring peak (rivers Iller and Wertach). The catchment areas of the rivers Lech and Isar, located in the central part of the investigation area, are denoted by a distinctly marked summer peak, followed in the eastern part with prolonged summer peaks (rivers Inn and Salzach). This spatial distribution is reflected by the seasonal distribution of the flood events indicated in Table 2.

Due to the spatial distribution of the catchment areas within the Northern Limestone Alps and the Bavarian Foreland, the highest proportion of summer floods occurs in the eastern river sections of the Inn $(79 \%)$ and the Salzach $(73 \%)$, followed by Isar (58\%) and Lech (57\%). Due to the lower extent of the Alpine catchment area, the rivers Iller and Wertach only have about $40 \%$ of the floods during summer. In total, a dominance of summer floods can be stated for the annual time series. Hereafter, the use of annual information is owed to minimized data quality and information before the 16th century. The flood-rich periods of the whole year (depicted in Fig. 6 by blue graph) and of the summer months (depicted in Fig. 8 by blue graph) correspond substantially to each other.

The investigation period of 1300-2008 covers the Little Ice Age (1300-1850) and the transition period to the Modern Climate Optimum as it is today. According to Wanner et al. (2000), it is advisable to differentiate the Little Ice Age into so-called Little Ice Age type events (LIATEs) addressing three major periods of extended glacier tongues. The periods, starting with LIATE3, are depicted for the years 1300-1380, $1570-1640$ and $1810-1850$.

\section{Database}

The body of historical source material corresponds to the wide range of settlements along the northern Alpine mountain rivers. All of the above-mentioned rivers host at least one notable historical site (among a multitude of other sites, e.g., Kempten (Iller), Augsburg (Lech/Wertach), Munich (Isar), Wasserburg (Inn), Burghausen (Salzach). Within the framework of a DFG (German Research Foundation)-funded research project, a database called IBT (Inundationes Bavariae Thesaurus; cf. Böhm 2011) was developed in cooperation with HISKLID (Historische Klimadatenbank Deutschland Historical Climatic Database of Germany - cf. Glaser, 2008). The former HISKLID has meanwhile migrated to the website https://www.tambora.org. Tambora is the acronym for the climate and environmental history collaborative research environment.

The IBT itself contains more than 32000 flood events within (central) Europe, all of them with a temporal relationship to the 584 independent flood events identified for the Bavarian Foreland (see below). The first investigation period was the period of documentary evidence from the 14 th century to the year 1880 . The data set of the period of written evidence includes more than 15000 flood events. The evaluated written evidence originated from manuscripts and chronicles (e.g., the Historische Kommission der Bayerischen Akademie der Wissenschaften - Historical Commission of the Bavarian Academy of Sciences - has pub- 
Table 1. Reference data of the Bavarian Foreland rivers, modified after different authors. The information under "Medium discharge summer" refers to the lowest official downstream gauge.

\begin{tabular}{lllll}
\hline River & Headwaters & $\begin{array}{l}\text { River } \\
\text { length }\end{array}$ & $\begin{array}{l}\text { Overground } \\
\text { catchment area }\end{array}$ & $\begin{array}{l}\text { Medium discharge } \\
\text { summer }\end{array}$ \\
\hline Iller & Allgäu High Alps (Germany) & $\sim 160 \mathrm{~km}$ & $2215 \mathrm{~km}^{2}$ & $79.3 \mathrm{~m}^{3} \mathrm{~s}^{-1}$ (Gauge Wiblingen) \\
Wertach & Allgäu Alps (Germany) & $\sim 135 \mathrm{~km}$ & $1290 \mathrm{~km}^{2}$ & $16.7 \mathrm{~m}^{3} \mathrm{~s}^{-1}$ (Gauge Türkheim) \\
Lech & Rhaetic Alps (Austria) & $\sim 250 \mathrm{~km}$ & $4162 \mathrm{~km}^{2}$ & $136 \mathrm{~m}^{3} \mathrm{~s}^{-1}$ (Gauge Augsburg) \\
Isar & Karwendel Mountains (Austria and Germany) & $\sim 260 \mathrm{~km}$ & $8960 \mathrm{~km}^{2}$ & $191 \mathrm{~m}^{3} \mathrm{~s}^{-1}$ (Gauge Plattling) \\
Inn & Maloja Pass (Switzerland) & $\sim 520 \mathrm{~km}$ & $26100 \mathrm{~km}^{2}$ & $972 \mathrm{~m}^{3} \mathrm{~s}^{-1}$ (Gauge Passau) \\
Salzach & Kitzbühl Alps (Austria) & $\sim 220 \mathrm{~km}$ & $6700 \mathrm{~km}^{2}$ & $332 \mathrm{~m}^{3} \mathrm{~s}^{-1}$ (Gauge Burghausen) \\
\hline
\end{tabular}

Table 2. Seasonal distribution of flood events (percentages refer to the individual outer-Alpine river sections) in the Bavarian Foreland for the period from the 14th century to 2008 .

\begin{tabular}{lllllll}
\hline & Iller & Wertach & Lech & Isar & Inn & Salzach \\
\hline Summer & $42 \%$ & $39 \%$ & $57 \%$ & $58 \%$ & $79 \%$ & $73 \%$ \\
Spring & $16 \%$ & $20 \%$ & $14 \%$ & $14 \%$ & $10 \%$ & $6 \%$ \\
Winter & $28 \%$ & $23 \%$ & $12 \%$ & $12 \%$ & $2 \%$ & $7 \%$ \\
Autumn & $14 \%$ & $18 \%$ & $17 \%$ & $16 \%$ & $9 \%$ & $14 \%$ \\
\hline
\end{tabular}

lished 37 volumes of city chronicles between 1862 and 1968), annals, historical (daily) newspapers of the investigated area (cf. e.g., Augsburger Postzeitung 1833-1935 and Innsbrucker Nachrichten 1854-1945), compilations (e.g., Sonklar, 1883; Weikinn, 1958, 1960, 1961, 1963; Alexandre, 1987; Fliri, 1998; Stahleder, 1995-2005; Börngen and Tetzlaff, 2000, 2002; Brázdil, 2005), un-edited historical leaflet databases (Schorn $\uparrow 1937$, Ferdinandeum Innsbruck Administration of Inheritance) and already existing databases (Militzer, 1998; Glaser, 2008) which were re-examined with a focus on the Bavarian Foreland. Due to the approach explained below written evidence of the middle reaches and tail waters has been considered.

To highlight some selected sources, the Chroniken deutscher Städte (Chronicles of German Cities 1862-1968) focused on the city of Augsburg on the river Lech and the publications of Stahleder (1995-2005) for the city of $\mathrm{Mu}$ nich on the river Isar will be introduced briefly. Inside the Chroniken deutscher Städte the history of Augsburg is organized into Die Chroniken der schwäbischen Städte (The chronicles of Swabian Cities). In total nine volumes are existent for the second oldest city of Germany, including substantial information about the river Lech floods. Within these nine volumes the following chronicles have been edited: Volume 1 (1865) contains the Augsburger Anonyme Chronik from 1368 to 1406 with proceedings until 1447, the chronicle by Erhard Wahraus from 1126 to 1445 with supplements until 1462 and the chronicle from the foundation of the city of Augsburg until 1469. Volume 2 (1866) contains the chronicle by Burkard Zink from 1368 to 1468 . Volume 3 (1892) con- tains the chronicle by Hector Mülich from 1348 to 1487 and the anonymous chronicle from 991 to 1483 . Volume 4 (1894) includes the chronicle from the oldest time of the city until 1536 plus proceedings of the chronicle by Hector Mülich. Volume 5 (1896) contains Cronica newer geschichten by Wilhelm Rem, 1512-1527, Johannes Frank's Augsburger Annalen from 1430 until 1462 and supplements concerning the chronicle by Clemens Sender. Volume 6 (1906) contains the chronicle of Georg Preu from 1512 until 1537. Volume 7 (1917) contains two chronicles by the apparitor Paul Hektor Mair. Volume 8 contains The Diary of Paul Hektor Mair from 1560 to 1563 and the second chronicle by Paul Hektor Mair from 1547 to 1565 . Volume 9 contains the weaver chronicle by Clemens Jäger from 955 to 1545 .

Helmuth Stahleder, ex-alternate director of the Stadtarchiv München (City Archive Munich) evaluated data within the city archive of Munich to compensate the missing of history of Munich within the Chroniken deutscher Städte. The foundations of this compilation among others are original documents, calculations of the city treasurer and yearbooks. The result of the longstanding investigation was the Chronik der Stadt München, three volumes concerning the history of $\mathrm{Mu}$ nich between the years 1157 and 1818. A multitude of flood events along the river Isar are recorded within the Chronik der Stadt München. Each record is furnished with a related city archive reference.

The early instrumental records in the Bavarian Foreland started in 1826. More than 20 historical gauge station records were examined. The data set of EIP/MIP (modern instrumental period) includes about 17000 flood events of the Bavarian Foreland (MIP). The data were analyzed with respect to monthly maxima of the water level. Taking physical structures and vertical erosion of gauge stations into account, the gauge datum has been changed in some cases, sometimes even repeatedly. A high-pass filter was applied to homogenize the data. In the present paper we choose one representative gauge station for each river, each with the longest coherent time series since 1826. They include the time series of Kempten (Iller), Landsberg am Lech (Lech), Landshut (Isar), Wasserburg (Inn) and Burghausen (Salzach). The EIP time series of the river Wertach was merged between 
overlapping periods, verified by a high Pearson correlation coefficient $(r=0,86)$ between the data from the gauge stations Ettringen and Augsburg/Oberhausen. From 1900 onward data were available from the Bavarian Water Authority.

Within the IBT all data sets are organized by the following parameters: identification number, event date as accurate as possible (most records are available in daily and monthly resolution), duration of flood, rainfall, location with geographic coordinates, river relationship, reference and coding concerning hydrological and climatological parameters and source text. All data of the Bavarian Foreland have been recorded and coded for tambora.org. The activation of the elaborated database should soon be realized.

To merge the different data periods, we used the following approach. To compare flood events from written historical sources with flood events measured by water level or discharge during the instrumental period, we used an existing intensity classification of historical floods which was adapted to the instrumental period. According to the scheme of Sturm et al. (2001), the flood events were classified into three intensity levels. The classification is based on damage reports and descriptions of weather conditions if available. If flood events were mentioned in rudimentary descriptions only or there was little or minor damage, the event was classified as a regional flood (intensity Level 1). If damage of waterrelated structures (e.g., bridges, weirs and mills) or buildings near the rivers were reported or if there were indicators for long-lasting flooding of farmland, Level 2 was assigned to the flood. The criteria for catastrophic floods, reported from different river systems, are severe damage or destruction of water-related structures, loss of lives, long-lasting flooding of wide areas and geomorphological changes in the fluvial system; those were classified as Level 3 . The selected instrumental data are based on the monthly maxima water level or discharge. The mean values of these measurements plus 1,2 or 3 standard deviations define the thresholds for the classification of the instrumental data (in case of water level data, high-pass-filtered data were used; see Methods). According to the experience in working with historical flood information, all floods of intensity levels 1, 2 and 3 from the period of documentary evidence were considered, whereas Level 1 events from the instrumental period were disregarded. An overlapping period (1826-1880) between the descriptive and the instrumental periods supports this procedure. Samples of rudimentary descriptive flood information have shown that the historical flood information through time is traditionally based on strong events for the most part (cf. Böhm, 2011). In Table 3 all flood events used for the merged time series of flood frequency in the Bavarian Foreland (cf. Figs. 3 and 4) are listed. The data for the time series of the Bavarian Foreland are derived from 1825 different flood records in total, which can be assigned to 584 independent flood events.

To expand the data basis as wide as possible we have applied a methodical practice we have named the "non-critical approach" (NCA; cf. Böhm, 2011). The NCA is a procedure especially designed for extraordinary hydrological events. Within the range of historical climatic data, flood information has an exceptional position. Common threads connecting available flood information are damages. The main argument for the NCA is based on the reasonable assumption that historical flood reports - due to the particular burden - contain more objective information than other descriptions of climatic events. In the center of this approach stands the transfer of the gist "flood" through time. The starting point of this approach was the fundamental question if anonymous sources in general may be regarded as verified sources (cf. e.g., Augsburger Anonyme Chronik von 1368 bis 1406 in Die Chroniken der schwäbischen Städte. Augsburg, Band 1. Leipzig 1865). According to a rigorous interpretation of source criticism, all of the (environmentally related) information from this source would have to be discarded. Based on the NCA we use all available sources and information about flood events of the outer-Alpine river sections concerning the period of documentary evidence. Avoiding classical source criticism, the NCA contributes to increase acquisition of information and reduces the thinning of relevant information during times of limited flood documentation. This approach minimizes the loss of original written records concerning historical flood information due to anthropogenic or natural calamities.

To verify the NCA, various stress tests were performed. Glaser et al. (2002) state that a spatial criterion for the distribution pattern of weather/climatic causes can be implied by sufficient data density. Within the scope of the NCA a spatiotemporal/synoptical criterion has been consulted to verify historical data. All superior flood events of the Bavarian Foreland have been visualized by spatiotemporal flood distribution patterns with the assistance of geographic information systems. Therefore, plausible (spatiotemporal/synoptical) evidence for the validity of flood information can be adduced. Further confirmation was given by cross-comparison with verified records, e.g., HISKLID (cf. Böhm, 2011).

Environmental psychological aspects provide further backing for the NCA. In brief, damaging flood events have an exceptional position in cultural history and the transfer of information through time based on primal fear remains. A more detailed description of the NCA is to be found in Böhm (2011).

\section{Methods}

In Fig. 2 the monthly maxima of water levels, exemplified by the gauge at Ettringen/Wertach (35 km south of Augsburg) before (a) and after (b) high-pass filtering are depicted. Figure $2 \mathrm{a}$ shows the deepening of the riverbed due to anthropogenic encroachment into the river system. The process of riverbed deepening started around 1860. Since the administration did not change the datum of the measuring device for 
Table 3. Synoptic table of the data basis for flood frequency in the Bavarian Foreland. Columns (a)-(c) contain all outer-Alpine flood events of documentary evidences until 1880, segmented at intensity levels. Columns (d) and (e) contain all floods derived from instrumental periods until 2008 for one representative gauge per river. EIP: early instrumental period, MIP: modern instrumental period.

\begin{tabular}{llllll}
\hline River & (a) Level 1 & (b) Level 2 & (c) Level 3 & (d) EIP/MIP level 2 & (e) EIP/MIP level 3 \\
\hline Iller & 32 & 53 & 15 & 45 & 13 \\
Wertach & 37 & 79 & 20 & 66 & 16 \\
Lech & 101 & 159 & 80 & 78 & 38 \\
Isar & 88 & 101 & 29 & 55 & 18 \\
Salzach & 154 & 113 & 78 & 56 & 22 \\
Inn & 79 & 82 & 63 & 48 & 7 \\
\hline
\end{tabular}

a time, but extended the measuring sticks of the gauges into the negative range instead, a total riverbed incision of more than $6 \mathrm{~m}$ within 30 years is documented. Furthermore, the first countermeasures (like lateral water buildings) obviously occurred around 1870. Around 1885 the incision seems to have stopped. After a short data gap around 1895, two datum changes can be identified. The high-pass filtering seems to be the most suitable method to address these different changes.

In order to be able to properly understand the long-term development of flood events in the Bavarian Foreland, ztransformed 31-year running flood frequencies have been calculated in several studies (e.g., Glaser, 2008; Glaser and Stangel, 2003b; Böhm and Wetzel, 2006; Sturm et al., 2001; Schmoecker-Fackel and Naef, 2010). The 31-year time step is derived from the standard reference period of the World Meteorological Organization. This time segment is an established tool to identify the linkage of climatic coherence of time series and exhibits significant changes in flood frequencies. Although this measure results in a comparatively poor filtration effect it still meets the needs of various geoscientific approaches to define climatological phases (Schönwiese, 1992).

Due to their geomorphological shapes the catchment areas of the investigated rivers have been divided in an innerand outer-Alpine region. Only the outer-Alpine regions (see Fig. 1 dashed line) have been considered for the present paper. To reveal the flood sensitivity of the entire Bavarian Foreland, all flood events of the outer-Alpine region have been merged into one overall time series. The highest classification according to damage reports has been counted, whereas local events caused by e.g., flash floods have not been counted. Hence, only mesoscale hydrological events have been incorporated into the present analysis.

In order to integrate different historical sources and locations referring to one meteorological event, a time window including a maximum number of 7 days before and after a designated event has been introduced. Therewith, the varying duration of hydro-meteorological sequences (from the genesis of synoptic disturbances to the termination of flood waves) as well as the blur of historical information can be considered. For example, the summer flood of the year 1501, being one of the biggest floods since the beginning of written records (quantitative evidence in terms of a flood mark is located at the Fischmarkt in Passau, Bavaria), has been recorded more than 150 times in the IBT, yet it is counted only once in the 31-year running flood frequency of the Bavarian Foreland.

The determination of flood-rich and flood-poor periods is based on a polynomial function of the fifth degree for the running flood frequencies (see black graph in Fig. 4). This method has been adapted from Glaser et al. (2004), who used polynomial functions to visualize long-term development of climatic elements. Using this function the inhomogeneity of the number of cases could best be confronted. Different databases and data densities (e.g., 14th/15th century turn of the 15th to 16th century - beginning of the instrumental period) were thus considered as far as possible. This method does not claim precision for the beginning and the end of the defined periods; however, compared to a multitude of other methods and due to the changing data density over time, it is the highest-performance method. Different methodical approaches with the aid of quantiles as medians or percentiles could not achieve satisfactory definitions for the generated time series and its comparability. The determined periods should come over as the results of a sensitivity analysis. The fixing of the threshold based on a polynomial function of the fifth degree coincides with the fracture points of the $t$ test analyses (cf. Fig. 5), so the method is provided by statistical measure.

In general, the intervals above/below the function graph are defined as flood-rich/flood-poor periods. Due to the changing data basis over the entire time series, it was necessary to interpolate in some cases (compare e.g., flood-rich period \#2). With respect to the differing data density as a function of time and not as an increasing frequency in general, the values in Fig. 4 have been $z$-transformed. So the weak data density until the beginning of the 16th century is denoted by values beneath the zero line. Therewith, the under- and over-representative availability of data has been taken into account.

For merging the single outer-Alpine time series, all flood events which took place isochronally (under consideration of 

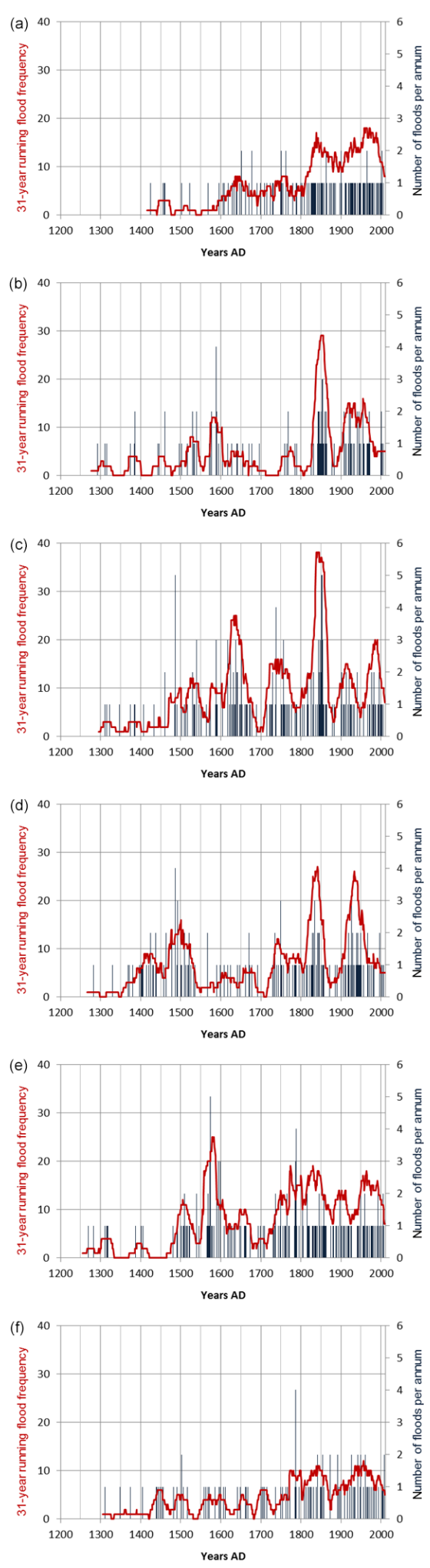

Figure 3. The 31-year running flood frequencies of the Bavarian Foreland rivers (red graph). Right ordinate: dark columns show the annual flood frequencies. (a) Iller, (b) Wertach, (c) Lech, (d) Isar, (e) Salzach, and (f) Inn.

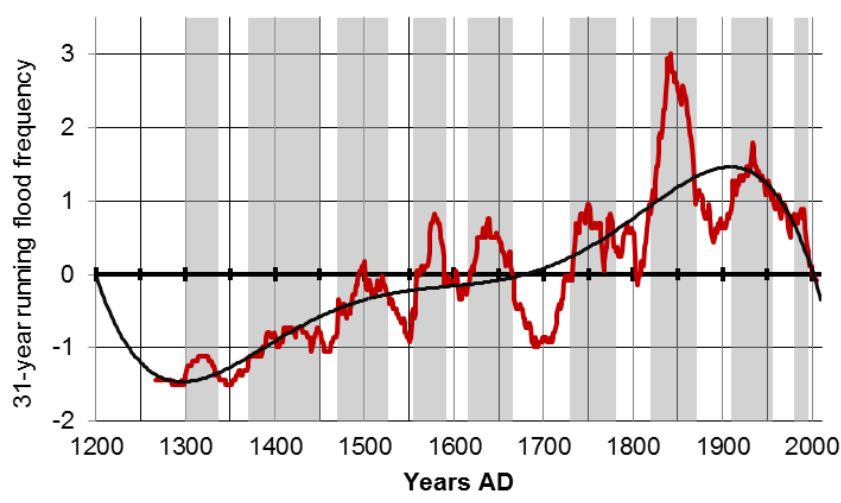

Figure 4. The 31-year running $z$-transformed flood frequencies of the Bavarian Foreland. Grey bars label flood-rich periods \#1-\#9, the black graph indicates the polynomial of 5 th degree.

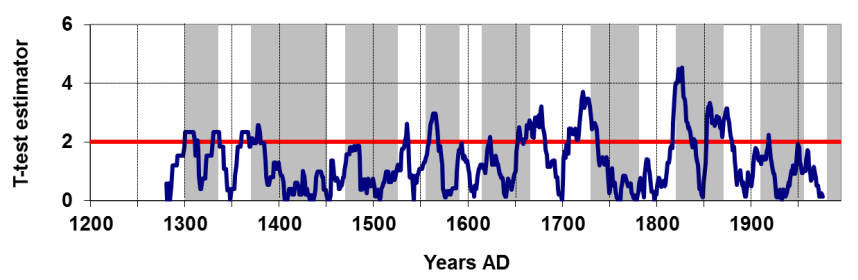

Figure 5. Differences of sliding means by the 31-year running $t$ test estimator of flood frequencies of the Bavarian Foreland; the threshold value for the two-sided $t$ test is 2.00 (see red line). Grey bars indicate flood-rich periods \#1-\#9.

the above-mentioned time window) have been counted only once. Virtually all counted events can be affirmed with a plurality of flood events which occurred isochronally within the investigation area as well as in a (central) European context.

\subsection{Statistical significance}

The time series for the Bavarian Foreland has been submitted to a two-sided $t$ test which can identify fracture points within the time series (cf. Glaser and Stangl, 2003b). The fracture points reveal differences between the means of sliding flood frequencies. The differences shown by estimators above the threshold are expected to detect significant coherence between superior framework conditions like variations of large-scale atmospheric circulation and consequential variability of flood-poor and flood-rich periods. The $\alpha$ level of 0.05 (solid line) is depicted in Fig. 5. Most of the detected fracture points coincide with changes in atmospheric conditions (see next section). The flood frequency time series of the Bavarian Foreland has additionally been correlated with reconstructed NAO (North Atlantic Oscillation) index values (cf. Luterbacher et al., 2002a) as well as with moving mean sunspot numbers (data after Hoyt and Schatten, 1997). Significant correlations between these quantities include the consideration of inherent autocorrelations (cf. Werner, 2002). 


\section{Results}

In Fig. 3 all single time series of the examined catchment areas are depicted. Taking comparability into account all axes have the same scale of values. The itemized time series of the rivers Iller (a), Wertach (b), Lech (c), Isar (d), Salzach (e) and Inn (f) are the foundation of the overall time series of the Bavarian Foreland depicted in Fig. 4.

In Fig. 4 the merged flood history of the Bavarian Foreland between $1300 \mathrm{AD}$ and 2010 is depicted. The data for that time series is derived from 1825 different flood records of the itemized time series (c.f. Fig. 3) which are assigned to 584 independent flood events. Based on a polynomial function of the fifth degree (see red line), nine flood-rich and eight flood-poor periods can be identified. As identified in the Methods section, due to changing data density over time, it is the highest-performance method, and the determined periods constitute the results of a sensitivity analysis. In particular, the rising data density after the mid-15th century must be seen in a context of the invention of letterpress, among other social reasons and changes. From 1826 onward measured data daily resolution are available.

Single flood-rich periods will be discussed below. In order to prove significant changes within the time series of the 31-year running flood frequencies of the Bavarian Foreland, we have depicted the estimators of the $t$ test in Fig. 5 (cf. Glaser and Stangl, 2003b). In this context, changing climatic parameters like the NAO index and the sunspot numbers will be briefly approached (a more extensive discussion will follow subsequently).

\subsection{Flood-rich period \#1: 1300-1335}

The first flood-rich period, although based on low data density, can be associated with changes in the atmospheric framework. Within the investigation area at least 16 records could be extracted from compilations like in Alexandre (1987), different chronicles (cf. e.g., von Zillner, 1885; Schnurrer, 1823) and the Augsburger Urkundenbuch no. 264 (cf. Groos, 1967). Despite small data density, significant changes of climatic parameters at the beginning and the end of this flood sensitive period can be stated and should not be withheld.

Wanner et al. (2000) date the onset of the Little Ice Age at the beginning of the 14th century, based on Miller et al. (2012), triggered by multiple volcanic eruptions. Period \#1 coincides with the beginning of LIATE3, the first period of advancing glacier tongues during the Little Ice Age, additionally enhanced by the Wolf solar activity minimum (1282-1342, cf. Glaser, 2008). Following the sunspot numbers after Usoskin et al. (2004), the first flood-rich period coincides with a period of sunspot minima. According to Fig. 5, the $t$ test value shows significant changes with the beginning and the end of period \#1. The estimator declines during the flood-active phases (this can be identified for most flood-rich phases). While LIATE3 approaches a climax, the flood frequencies decline considering a time lag due to mass input into the Alpine glaciers (cf. Wanner et al., 2000). Most of the significant fracture points in Fig. 5 coincide with the beginning and the end of the flood-rich or flood-poor periods in Fig. 4. A further qualitative confirmation for particular climatic circumstances during that period is provided by Lamb (1980).

\subsection{Flood-rich period \#2: 1370-1450}

The increase of flood frequencies is accompanied by significant $t$ test estimators. Despite the absence of significant estimators, the end of period \#2 coincides once more with changing climate conditions characterized by the beginning of the Spoerer Minimum, another sunspot minimum between the years 1450 and 1534 (cf. Glaser, 2008).

\subsection{Flood-rich period \#3: 1470-1525}

The transitional period between the flood-poor period \#2 and the flood-rich period \#3 coincides with an obviously rising estimator (significant at the $\alpha$ level 0.05 ) as well as with the end of a distinct period of negative temperature anomalies in the Alps (cf. Wanner et al., 2000). The end of period \#3 is once again marked by highly significant $t$ test estimator values. The maximum value is accompanied by the end of the Spörer Minimum, again an indication for changing climate conditions which affect the flood frequencies in the Bavarian Foreland.

From 1500 onward we can use reconstructed NAO index (NAOI) values (cf. Luterbacher et al., 2002). The end of period \#3 (i.e., first grey bar in Fig. 6) is accompanied by an obvious declining NAOI for annual (Fig. 6) as well as summer seasonal values (Fig. 8). Due to the impact of precipitation to the entire hydrological year on flood progress, the fullyear development of the NAO may reflect mean weather conditions. In general, however, the correlation between weather conditions and the NAOI is more significant during winter than during the warmer half of the year.

\subsection{Flood-rich period \#4: $1555-1590$}

Between the years 1550 and 1700 the $z$-transformed NAOI values are generally characterized by low index values. Within this period, variations in flood frequencies can be identified (see Fig. 6) with increasing and declining values accompanied by rising and falling NAOI values, respectively, for the whole year as well as for the seasons winter (not shown) and summer (cf. Fig. 8). The $t$ test estimator indicates significant values (>2.00 at a $\alpha$ level of 0.05$)$ at the beginning and at the end of period \#4 (cf. Fig. 5). The flood frequency maximum coincides with a distinct period of negative temperature anomalies that lead into LIATE2. 


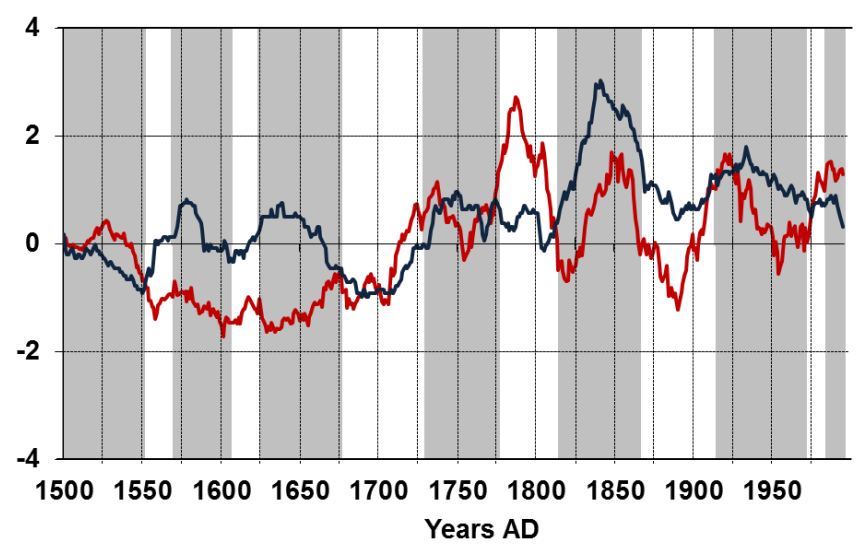

Figure 6. The $z$-transformed time series of annual 31-year running flood frequencies in the Bavarian Foreland (blue) and of annual 31year running NAOI (red) (NAOI data after Luterbacher et al., 2002). Grey bars indicate the flood-rich periods \#3-\#9 based on the fullyear development.

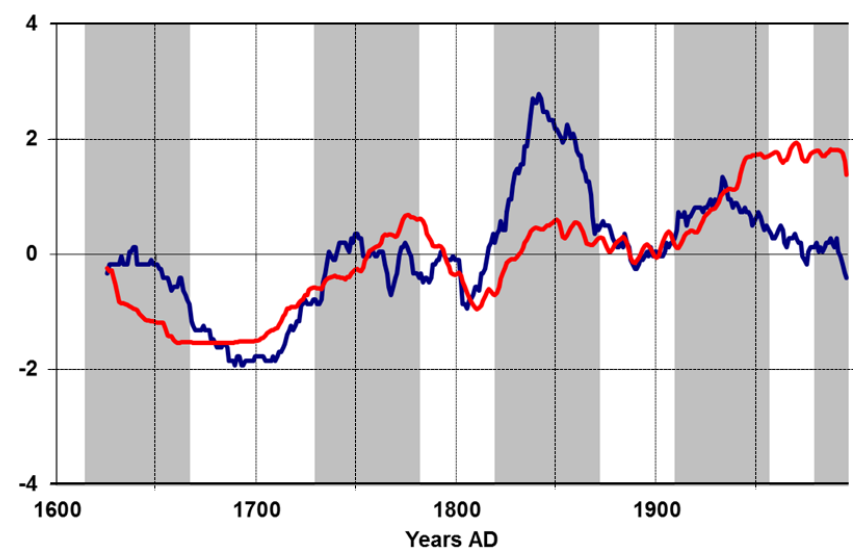

Figure 7. The $z$-transformed time series of annual 31-year running flood frequencies in the Bavarian Foreland (blue) and "sunspot activity" (red) since 1610 (data for sunspot activity modified after Hoyt and Schatten, 1997). Grey bars indicate the flood-rich periods \#5-\#9 based on the full-year development.

\subsection{Flood-rich period \#5: 1615-1665}

Period \#5 is again accompanied by significant $t$ test estimators for the beginning as well as for the end (see Fig. 5). The transition period between period \#5 and the Maunder Minimum (1645-1715; cf. Schönwiese, 2008) is accompanied by a conspicuous behavior of the $t$ test estimator, a possible evidence for unsettled atmospheric conditions. Period \#5 took place during LIATE2 (1570-1640; cf. Wanner et al., 2000); the retreat of the glacier tongues (peak around 1650) coincides with declining flood frequencies. Period \#5 also fell into a period of declining sunspot numbers which have been directly observed for the first time since 1610 (cf. Fig. 7). The absolute minima of sunspots in 1660 turned into the Late Maunder Minimum and they were accompanied by the ab-

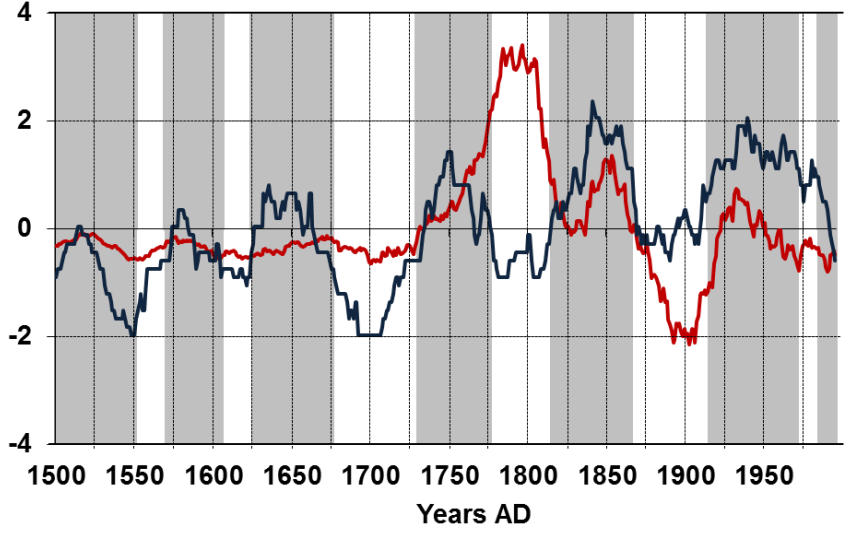

Figure 8. The $z$-transformed time series of 31-year running flood frequencies in the Bavarian Foreland (blue) and NAOI values (red) for the meteorological summer (JJA) (NAOI data after Luterbacher et al., 2002). Grey bars label the flood-rich periods \#3-\#9.

solute flood frequency minimum from 1500 till today. With the beginning of immediate observation of sunspots we can refer to a distinct correlation between the 31-year moving sunspot numbers and flood-rich and flood-poor periods until 1930. The end of LIATE2 coincides with the beginning of the Maunder Minimum; compare Fig. 7 and Wanner et al. (2000).

The flood frequencies are rising while the mean NAOI values for the complete year are declining; the flood frequency peak coincides with minimal NAOI values. The following decline of the flood frequencies is accompanied by rising NAOI values (see Figs. 6 and 8). The development of the winter NAOI reveals a different pattern. The absolute maximum value of flood frequencies coincides with a short-termed increase of the winter NAOI. This could indicate wet winter conditions resulting in vast water retention which could favor summer floods during snowmelt.

\subsection{Flood-rich period \#6: 1730-1780}

Period \#6 is once again marked by significant $t$ test estimators during increasing flood frequencies; the end of the period is marked by a distinct evolution of the estimator values. The $t$ test estimators in general will not show significant variations for the next 80 years (cf. Fig. 5). Period \#6 is accompanied by a noticeable development of the NAOI values. The year-round development shows a parallel increase of flood frequencies and NAOI values; however, during the flood frequencies" peak, the NAOI values decline in a distinct way (cf. Fig. 6). The development of the Little Ice Age in terms of glacier tongue movements shows a slight stagnation.

The following flood-poor years until 1820 are characterized by the next sunspot minimum, the Dalton Minimum (1790-1830; cf. Schönwiese, 2008), again accompanied by relatively low flood frequencies (see Figs. 3 and 4). 
The end of the Dalton Minimum and the beginning of the next flood-rich period is accompanied by extreme flood frequencies (cf. Fig. 4) as well as extraordinary $t$ test estimators (cf. Fig. 5). Reasons for that will be explained below.

\subsection{Flood-rich period \#7: 1820-1870}

Period \#7 is marked by a changing database (transition between documentary period and early instrumental period). In addition, it represents the beginning of the transition period between the end of the Little Ice Age and the beginning of the Modern Climatic Optimum as well as the beginning of (systematic) anthropogenic interference into the natural river systems. Thus, period \#7 falls into a section of different overlapping trends. The $t$ test estimators reveal this transition at the beginning of the period (unique $t$ test estimator values, see Fig. 5). The end of the period, based on $t$ test estimators, can be interpreted as inhomogeneous climatic conditions during the transition to the Modern Climatic Optimum. The increasing flood frequencies of period \#7 coincide with increasing sunspot numbers (cf. Fig. 7).

The development between LIATE1 (1810-1850) and period \#7 requires a particular reflection, as LIATE1 and the flood-rich period end at about the same time, whereas the preceding LIATEs (\#3 and \#2) did not end at the same time like the corresponding flood-rich periods. The maxima of the preceding LIATEs fall into intervals of low flood frequencies framed by the end and the beginning of flood-rich periods. A noticeably aligned development between the NAOI values and the flood frequencies can be highlighted for the whole year as well as for the summer and winter seasons (cf. Figs. 6 and 8). The following years are characterized by both declining flood frequencies and NAOI values. In this context we can generally identify an increasing impact and significance of the summer NAOI for the development of flood frequencies in the Bavarian Foreland (discussion see below).

\subsection{Flood-rich period \#8: 1910-1955}

Period \#8 is once more framed by significant $t$ test estimators with a final significant estimator value within the time series (see Fig. 5). Until 1930, similarities (or correlations) between flood frequencies and sunspot numbers did exist. After that, the time series seem to be decoupled, as depicted in Fig. 7. The beginning of period \#8 coincides with rising NAOI values, the amplitude of these values in general shows a parallel development (cf. Figs. 6 and 8).

\subsection{Flood-rich period \#9: 1980-?}

A last flood-rich period starts in 1980 intersecting with the end of the time series. Due to the use of 31-year running quantities, its validity remains unclear.

\subsection{The flood frequencies of the Bavarian Foreland accompanied by different climatic conditions in detail}

\subsubsection{The correlation of flood frequencies and sunspot numbers}

The meaning of varying solar activity for the climatic conditions is currently a matter of fierce discussion (cf. Shindell et al., 2001; Feulner and Rahmstorf, 2010; Feulner, 2011). Generally the variability of solar activity can affect large-scale atmospheric circulation including climate parameters like temperature, precipitation and transpiration (cf. Endlicher and Gerstengarbe, 2009). Despite uncertainty in the way in which solar activity could have an effect on climate development within the research area, it can be shown that solar trends (of different signs) coincide with changing climatic conditions affecting the flood frequencies in the Bavarian Foreland. Within these relationships, one certain conspicuousness must be emphasized but not discussed in detail at this point. One has to distinguish between direct observations or reconstructions based on proxy data. Both periods differ with respect to the sign of the correlation between flood frequencies and solar activity. In general, before direct observations started, high flood frequencies coincided with reduced solar activity, while then flood-rich periods coincided with increased solar activity. The best fit between the 31-year running frequencies is achieved with direct observations starting in 1610 and ending around 1930 (cf. Fig. 7). The year 1930 occupies a special position which will be discussed later. Considering the four sun-spot minima encompassed within the investigation period, we can denote the following:

The Wolf Minimum ( 1280-1340) coincides with the first calculated flood-rich period. This temporal correspondence between high flood activity and low sunspot numbers is unique within the total time series (cf. Fig. 4).

The duration of the Spörer Minimum differs among a number of authors. According to Glaser (2008), the Spörer Minimum takes place between the years 1450 and 1534, whereas Schönwiese (2008) identifies the years 1400-1510. According to the first definition of the Spörer Minimum, another sunspot minimum coincides with a flood-rich period (here period \#3). Keeping with the sunspot data of Usoskin et al. (2004), the flood frequency maximum of period \#3 also corresponds to the low sunspot numbers of the Spörer Minimum.

With the beginning of the Maunder Minimum period, the indication of the relationship changes. As depicted in Fig. 7 running flood frequencies and sunspot numbers are varying in a similar way. The course of both graphs during the Dalton Minimum (1790-1830) again shows a similar development. These data indicate a significant trend, between the years 1610 and 1995 the Pearson correlation coefficient amounts to 0.62 and between 1700 and 1930 to 0.7 . Autocorrelation could be achieved by using the effective sample size based 
on a method by Werner (2002), which regards the statistical persistence of database-inherent autocorrelations $(\alpha=0.01)$. After 1930, the relationship of sunspot numbers and flood frequencies seems to be decoupled. A comparison of global temperatures and GAR (greater Alpine region) temperatures shows a temperature leap over the calculated neutral-point temperature development since the beginning of the early instrumental period (cf. Auer et al., 2007).

Not all flood-rich and flood-poor periods can be connected to sunspot minima or maxima, but all sunspot extremes can be connected to changes of overall climatic conditions irrespective of its trends (cf. Böhm, 2011)

\subsubsection{Correlations of flood frequencies and NAOI values in detail}

Is it possible to associate (in a statistical sense) the variability of the NAO and the flood history of the Bavarian Foreland? Due to oscillations of barometric pressure between the Iceland cyclone and Azores anticyclone weather conditions of the Atlantic affects western Europe climate in various ways. Based on the reconstruction of the NAOI by Luterbacher et al. (2002), the time series of the flood frequencies (31-year running mean values) and of the NAOI (likewise 31-year running mean values) can be compared from $1500 \mathrm{AD}$ onward (cf. Figs. 6 and 8). The NAO is one of the dominating teleconnection patterns regulating the regional characteristics of many climatic parameters. The NAO also reveals seasonal variations (in context of the climatic seasonal cycle).

The annual and summer time series of flood frequencies and of NAOI values have been compared. The comparisons of the annual valuables are depicted in Fig. 6 and the comparisons of the summer seasons in Fig. 8. The particular importance and the general dominance of summer floods in the Bavarian Foreland have already been discussed. The winter flood occurrences are mainly relevant in terms of the retention potential of the Alpine catchment areas which supports the development of floods in general. In spite of the general decline of the NAO importance during summer, significant correlations of the NAO (index) and the time series of summer floods can be recognized. In a first step, 100-year intervals have been considered. For the centuries 1500-1599 ( $r=0.78, \alpha=0.01)$ and 1900-1999 $(r=0.65$, $\alpha=0.01$ ) significant positive correlations occur (once again verified by the calculated persistence). Shifting the timeinterval by 50 years, a significant correlation can be observed for the period 1650-1749 $(r=0.8)$. Furthermore, the years from 1830 to 1999 exhibit another highly significant correlation coefficient of $r=0.8(\alpha=0.01)$. The changing sign in the relationship around 1820 (cf. Fig. 8) coincides with the important transition period between the Little Ice Age and the Modern Climate Optimum.
Table 4. Comparison of selected flood frequencies. Lower Rhine (RHl), Middle Rhine (RHm), Czech Elbe (ELBcz), Vltava (VLA) and Bavarian Foreland (BF). Due to the decadal visualization, beginnings and endings of the marked periods underlie a certain blur. Data altered according to Glaser (2008) and Brázdil (1998).

\begin{tabular}{|c|c|c|c|c|c|c|}
\hline & RHl & RHm & $\mathrm{BF}$ & ELBcz & VLA & \\
\hline 1500 & & & $\mathrm{x}$ & $\mathrm{x}$ & $\mathrm{x}$ & 1500 \\
\hline 1510 & $\mathrm{x}$ & & $\mathrm{x}$ & & & 1510 \\
\hline 1520 & $\mathrm{x}$ & & $\mathrm{x}$ & & & 1520 \\
\hline 1530 & $\mathrm{x}$ & & & $\mathrm{x}$ & $\mathrm{x}$ & 1530 \\
\hline 1540 & & & & & & 1540 \\
\hline 1550 & & & & $\mathrm{x}$ & & 1550 \\
\hline 1560 & & $\mathrm{x}$ & $\mathrm{x}$ & $\mathrm{x}$ & $\mathrm{x}$ & 1560 \\
\hline 1570 & $\mathrm{x}$ & $\mathrm{x}$ & $\mathrm{x}$ & $\mathrm{x}$ & $\mathrm{x}$ & 1570 \\
\hline 1580 & $\mathrm{x}$ & $\mathrm{x}$ & $\mathrm{x}$ & & $\mathrm{x}$ & 1580 \\
\hline 1590 & $\mathrm{x}$ & & $\mathrm{x}$ & $\mathrm{x}$ & $\mathrm{x}$ & 1590 \\
\hline 1600 & & & & & & 1600 \\
\hline 1610 & & & & & $\mathrm{x}$ & 1610 \\
\hline 1620 & $\mathrm{x}$ & & $\mathrm{x}$ & & & 1620 \\
\hline 1630 & $\mathrm{x}$ & & $\mathrm{x}$ & & & 1630 \\
\hline 1640 & $\mathrm{x}$ & & $\mathrm{x}$ & & & 1640 \\
\hline 1650 & & & $\mathrm{x}$ & $\mathrm{x}$ & $\mathrm{x}$ & 1650 \\
\hline 1660 & & & $\mathrm{x}$ & $\mathrm{x}$ & & 1660 \\
\hline 1670 & & & & & $\mathrm{x}$ & 1670 \\
\hline 1680 & & $\mathrm{x}$ & & & & 1680 \\
\hline 1690 & & $\mathrm{x}$ & & $\mathrm{x}$ & & 1690 \\
\hline 1700 & & & & & & 1700 \\
\hline 1710 & & & & & $\mathrm{x}$ & 1710 \\
\hline 1720 & $\mathrm{x}$ & & & & & 1720 \\
\hline 1730 & $\mathrm{x}$ & & & & $\mathrm{x}$ & 1730 \\
\hline 1740 & $\mathrm{x}$ & & $\mathrm{x}$ & & $\mathrm{x}$ & 1740 \\
\hline 1750 & $\mathrm{x}$ & & $\mathrm{x}$ & & $\mathrm{x}$ & 1750 \\
\hline 1760 & & & $\mathrm{x}$ & $\mathrm{x}$ & & 1760 \\
\hline 1770 & & & $\mathrm{x}$ & $\mathrm{x}$ & $\mathrm{x}$ & 1770 \\
\hline 1780 & & & $\mathrm{x}$ & $\mathrm{x}$ & $\mathrm{x}$ & 1780 \\
\hline 1790 & $\mathrm{x}$ & & & $\mathrm{x}$ & $\mathrm{x}$ & 1790 \\
\hline 1800 & $\mathrm{x}$ & & & $\mathrm{x}$ & $\mathrm{x}$ & 1800 \\
\hline 1810 & $\mathrm{x}$ & & & $\mathrm{x}$ & $\mathrm{x}$ & 1810 \\
\hline 1820 & & & $\mathrm{x}$ & $\mathrm{x}$ & $\mathrm{x}$ & 1820 \\
\hline 1830 & & & $\mathrm{x}$ & $\mathrm{x}$ & $\mathrm{x}$ & 1830 \\
\hline 1840 & & & $\mathrm{x}$ & $\mathrm{x}$ & $\mathrm{x}$ & 1840 \\
\hline 1850 & & & $\mathrm{x}$ & & $\mathrm{x}$ & 1850 \\
\hline 1860 & & & $\mathrm{x}$ & & $\mathrm{x}$ & 1860 \\
\hline 1870 & & & $\mathrm{x}$ & & $\mathrm{x}$ & 1870 \\
\hline 1880 & & & & & $\mathrm{x}$ & 1880 \\
\hline 1890 & & & & & $\mathrm{x}$ & 1890 \\
\hline 1900 & & & & & $\mathrm{x}$ & 1900 \\
\hline
\end{tabular}

\subsection{Flood frequencies of the Bavarian Foreland in comparison with selected flood frequencies of central Europe}

This comparison is limited to the period between 1500 and 1900. The limitations result from weak data density in general before 1500 and in a multitude of anthropogenic over- 
prints of the river systems around the beginning of the 20th century. The comparison will be limited to the Lower Rhine and Middle Rhine (cf. Glaser, 2008), the Vltava (an Elbe tributary) and the Czech Elbe itself (cf. Brazdil, 1998). The comparison is depicted in Table 4. Due to the decadal visualization of beginnings and endings of the marked periods, they underlie a certain blur. Similarities for all time series can be particularly highlighted for the second half of the 16th century. In general an unexpected similarity can be seen between the time series of the Bavarian Foreland and the Lower Rhine, except the years 1790-1819. Good accordance in the Bavarian Foreland can be revealed for the first, seventh and eighth decades of the 16th century. During the 17 th century only the sixth decade shows good accordance. A further good accordance can be highlighted for the end of the 18th and beginning of the 19th century. Reasons for this variable behavior are founded in the variability of general synopsis and resulting weather conditions. In that context, the above-mentioned NAO plays a vital role. For a further understanding of the variability between the compared time series meteorological aspects must be consulted.

\section{Conclusions}

The flood history of the Bavarian Foreland can be analyzed in a statistical way from the beginning of the 14th century onward (based on the existing data). The flood history of the entire Bavarian Foreland was compiled and analyzed based on both documentary and instrumental data. We could identify statistical correlations between the flood frequencies and conditions of the atmospheric framework up to the present day based on different climate proxies and historical observations and transmissions.

The investigation period commences amid the latest climatic depression of the sub-Atlantic stage (2.5 ka-present). Despite the reduced availability of data at the beginning of the time series, including the absence of reconstructions of pressure fields, temperature and precipitation (until 1499), significant changes in the correlation between climate conditions and flood frequencies can be identified. Virtually each shift in the flood frequencies' trend (towards flood-rich or flood-poor periods) coincides with significant fracture points within the time series (according to two-sided $t$ tests). These fracture points provide indications of changing atmospheric conditions which may affect flooding.

The NAO is of particular importance for the climatic conditions in the Bavarian Foreland as well as in the Alps in general. However, according to Casty et al. (2005), the NAO alone cannot explain the very sophisticated climatic events of the GAR. The present work describes multiple mechanisms with influences to major atmospheric conditions. With a view towards the changing directions of the flood frequencies, the shifts themselves within multiple climatic factors are playing an important role in the climatic circumstances of flood de- velopment. In this context, the dominant role of the summer NAO from 1830 onward is conspicuous. This atmospheric parameter coincides with the beginning of the transition period between the Little Ice Age and the Modern Climate Optimum. Until the end of the time series, high correlation coefficients do exist. For this special period a statistical unique coherence within the present work can be emphasized.

Another influence on flood frequency development might come from solar activity. Despite marginal changes of global radiation, the correlation between flood frequencies and sunspot numbers from 1610 until 1930 is rather high. For the Maunder Minimum, the solar radiation was reduced by about $0.24 \%$ (compared with the present mean value; cf. Lean and Rind, 1998). This causes a cooling effect of $0.5^{\circ} \mathrm{C}$ for most of the Northern Hemisphere. Seemingly, the slight change of solar radiation could lead to a significant alteration of atmospheric fluxes, particularly concerning the moisture content of air masses. Nevertheless, the high correlation between flood frequency and solar activity cannot explain the mechanism of action from the solar surface through the atmospheric system towards the surface. To explain this mechanism of action further investigations are necessary.

After 1930 the natural relationships seem to be superimposed by an increasing anthropogenic influence on the climatic conditions. In this context a decoupling of a retrograde signal could be revealed. That assumption will be indicated by exceeding the threshold of the average temperature deviation for the GAR in 1930 (cf. Auer et al., 2007).

The current report emphasizes the importance of long time series. The complexity of Northern Hemisphere (or even global) circulation dynamics as well as the range of natural climate variability is, however, only partially understood.

Edited by: G. Blöschl

\section{References}

Alexandre, P.: Le Climat au Europe au Moyen age, Paris, 828 pp., 1987.

Auer, I., Böhm, R., Jurkovic, A., Lipa, W., Orlik, A., Potzmann, R., Schöner, W., Ungersböck, M., Matulla, C., Briffa K., Jones, P. D., Efthymiadis, D., Brunetti, M., Nanni, T., Maugeri M., Mercalli L., Mestre, O., Moisselin, J. M., Begert, M., Müller-Westermeier, G., Kveton, V., Bochnicek, O., Stastny, P., Lapin, M., Szalai, S., Szentimrey, T., Cegnar, T., Dolinar, M., Gajic-Capka, M., Zaninovic, K., Majstorovic, Z., and Nieplova, E.: HISTALP - historical instrumental climatological surface time series of the greater Alpine region 1760-2003, Int. J. Climatol., 27, 17-46, 2007.

Böhm, O.: Flood History of the Bavarian Foreland - The summer floods in context to the climatic history of Central Europe. PhD thesis (language German), Universität Augsburg, http://opus.bibliothek.uni-augsburg.de/opus4/frontdoor/index/ index/docId/2261, 2011.

Böhm, O. and Wetzel, K.-F.: Flood history of the Danube tributaries Lech and Isar in the Alpine foreland of Germany, Hydrol. Sci., 51, October 2006, Hist. Hydrol., 784-798, 2006. 
Börngen, M. and Tetzlaff, G. (Eds.): Weikinn, C. - Quellentexte zur Witterungsgeschichte Europas von der Zeitenwende bis zum Jahre 1850, Hydrographie, Bd. 5 (1751-1800), 2000.

Börngen, M. and Tetzlaff, G. (Eds.): Weikinn, C. - Quellentexte zur Witterungsgeschichte Europas von der Zeitenwende bis zum Jahre 1850, Hydrographie, Bd. 6 (1801-1850), 2002.

Brázdil, R.: The history of floods on the rivers Elbe and Vlatava in Bohemia, in: Erfurter Geographische Studien - Aktuelle und historische Hochwasserereignisse, edited by: Pörtge, K.-H. and Deutsch, M., 93-108, 1998.

Brázdil, R., Dobrovolný, P., Elleder, L., Kakos, V., Kotyza, O., Květoň, V., Macková, J., Müller, M., Štekl, J., Tolasz, R. and Valášek, H.: Historical and Recent Floods in the Czech Republic, Masaryk University and Czech Hydrometeorogical Institute, Brno, Prague, 370 pp., 2005.

Casty, C., Wanner, H., Luterbacher, J., Esper, J., and Böhm, R.: Temperature and precipitaion variability in the european Alps since 1500, Int. J. Climatol., 25, 1855-1880, 2005.

Deutsch, M. and Pörtge, K.-H.: Historical floods in Thuringia on the example of the flood in Langensalza on the 15th June 1815, in: Nature and society in regional context, edited by: Hlavinková, P. and Munzar, J., 4th Moravian Geographical Conference CONGEO '01, Brno/Czech Republic, 16-23, 2001.

Deutsch, M. and Pörtge, K.-H.: Erfassung und Bewertung historischer Hochwasserereignisse in Thüringen am Beispiel der Gera, in: Naturkatastrophen in Mittelgebirgsregionen, edited by: Fiedler, F., Nestmann, F. and Kohler, M., Proceedings of the symposium on 11 and 12 October 1999 in Karlsruhe, 185-212, 2002.

Deutsch, M., Böhner, J., Pörtge, K.-H. and Tilman Rost, K.: Untersuchung historischer Hochwasserereignisse in Thüringen dargestellt am Beispiel der Werra. Zeitschrift für Geomorphologie, Supplement Vol 135., Borntraeger Berlin, Stuttgart, August 2004, 11-23, 2004.

Die Chroniken der schwäbischen Städte: Augsburg, Bd. 1-9. Historische Kommission der Bayerischen Akademie der Wissenschaften (1862-1968): Die Chroniken der deutschen Städte. 37 Bände, Hirzel Leipzig, Perthes Stuttgart/Gotha, Schünemann Bremen, 1865 - 1928.

Endlicher, W. and Gerstengarbe, F.-W. (Eds.): Der Klimawandel Einblicke, Rückblicke und Ausblicke, http://edoc.hu-berlin.de/ miscellanies/klimawandel (last access: 1 December 2015), 2009.

Feulner, G.: Are the most recent estimates for Maunder Minimum solar irradiance in agreement with temperature reconstructions?, Geophys. Res. Lett., 38, L16706, doi:10.1029/2011GL048529, 2011.

Feulner, G. and Rahmstorf, S.: On the effect of a new grand minimum of solar activity on the future climate on Earth, Geophys. Res. Lett., 37, L05707, doi:10.1029/2010GL042710, 2010.

Fliri, F.: Naturchronik von Tirol, Innsbruck, Universitätsverlag Wagner, 369 pp. 1998.

Glaser, R.: Klimageschichte Mitteleuropas, 1200 Jahre Wetter, Klima, Katastrophen, 2. Auflage, Darmstadt, Wiss. Buchges, 264 pp., 2008.

Glaser, R. and Stangl, H.: Floods in central Europe since 1300, Palaeofloods, Historical Floods and Climatic Variability: Applications in Flood Risk Assessment, edited by: Thorndycraft, V. R., Benito, G., Barriendos, M., and Llasat, M. C., Proceedings of the PHEFRA Workshop, Barcelona, 16-19 October, 2002, 93$98,2003 \mathrm{a}$.
Glaser, R. and Stangl, H.: Historical floods in the Dutch Rhine Delta, Nat. Hazards Earth Syst. Sci., 3, 605-613, doi:10.5194/nhess-3-605-2003, 2003 b.

Glaser, R., Jacobeit, J., Deutsch, M. and Stangel, H.: Hochwasser als historisches Phänomen. Rundgespräche der Kommission für Ökologie der bay. Akademie der Wissenschaft, Bd. 24 Hochwasser und Ökologie - Katastrophe oder Chance?, 15-30, 2002.

Glaser, R., Beck, Ch., and Stangl, H.: Zur Temperatur- und Hochwasserentwicklung der letzten 1000 Jahre in Deutschland, DWD Klimastatusbericht 2003, 55-67, 2004.

Groos, W.: Beiträge zur Topographie von Alt-Augsburg, 21. Bericht der Naturforschenden Gesellschaft Augsburg, 127 pp., 1967.

Hoyt, D. V. and Schatten, K. H.: Group Sunspot Numbers: A New Solar Activity Reconstruction, Sol. Phys., 181, 491-512, 1997.

Jacobeit, J., Beck, Ch., and Philipp, A.: Annual to Decadal Variability in Climate in Europe, Würzburger Geographische Manuskripte, Heft 43, 1998.

Kiss, A. and Laszlovszky, J.: 14th-16th-century Danube floods and long-term water-level changes in archaeological and sedimentary evidence in the western and central Carpathian Basin: An overview with documentary comparison, J. Environ. Geogr., 6/34, 1-11, 2013.

Lamb, H. H.: Weather and Climate Patterns of the Little Ice Age. Das Klima. Analysen und Modelle, Geschichte und Zukunft, Springer, Berlin, Heidelberg, New York, 149-160, 1980.

Lean, J. and Rind, D.: Climate forcing by changing solar radiation, J. Climate, 11, 3069-3094, 1998.

Luterbacher, J., Xoplaki, E., Dietrich, D., Jones, P. D., Davies, T. D., Portis, D., Gonzalez-Rouco, J. F., von Storch, H., Gyalistras, D., Casty, C., and Wanner, H.: Extending North Atlantic Oscillation reconstructions back to 1500, Atmos. Sci. Lett., 2, 114-124, 2002.

Miller G. H., Geirsdóttir, Á., Zhong, Y., Larsen, D. J., Otto-Bliesner, B. L., Holland, M. M., Bailey, D. A., Refsnider, K. A., Lehman, S. J., Southon, J. R., Anderson, C., Björnsson, H., and Thordarson, T.: Abrupt onset of the Little Ice Age triggered by volcanism and sustained by sea-ice/ocean feedbacks, Geophys. Res. Lett., 39, L02708, doi:10.1029/2011GL050168, 2012.

Militzer, S.: Klima - Umwelt - Mensch, Band I - III. Abschlußbericht zum DFG-Projekt MI-493, Leipzig, 1998.

Mudelsee, M., Börngen, M., Tetzlaff, G., and Grünewald, U.: Extreme floods in central Europe over the past 500 years: Role of cyclone pathway "Zugstrasse Vb". J. Geophys. Res., 109, 1-21, doi:10.1029/2004JD005034, 2004.

Pfister, C.: Klimageschichte der Schweiz 1525-1860, Haupt, Bern/Stuttgart, 184 pp., 1984.

Pfister, C.: Häufig, selten oder nie, Zur Wiederkehrperiode der grossräumigen Überschwemmungen im Schweizer Alpenraum seit 1500, Jb. d. Geogr. Ges. Bern, Bd. 59, 139-149, 1996.

Pfister, C.: Wetternachhersage, Haupt Bern/Stuttgart, 1999.

Rohr, C.: Extreme Naturereignisse im Ostalpenraum, Naturerfahrung im Spätmittelalter und am Beginn der Neuzeit, Reihe: Umwelthistorische Forschungen 4, Böhnlau Köln 2007, 2008.

Rohr, C.: Floods of the upper Danube River and its tributaries and their impact on Urban economies (c. 1350-1600): The Examples of the towns of Krems/Stein and Wels (Austria), Environment and History 19/2 (2013), 133-148, 2013. 
Schmocker-Fackel, P. and Naef, F.: Changes in flood frequencies in Switzerland since 1500, Hydrol. Earth Syst. Sci., 14, 1581-1594, doi:10.5194/hess-14-1581-2010, 2010.

Schnurrer, F.: Die Krankheiten des Menschen-Geschlechts historisch und geographische betrachtet. Chronik der Seuchen in Verbindung mit den gleichzeitigen Vorgängen in der physischen Welt und in der Geschichte der Menschen, Erster Theil vom Anfang der Geschichte bis in die Mitte des fünfzehnten Jahrhunderts, Thübingen 1823, bei Christian Friedrich Osiander, 376 pp., 1823.

Schönwiese, C.-D.: Praktische Statistik für Meteorologen und Geowissenschaftler, Borntraeger, Berlin, 231 pp., 1992.

Schönwiese, C.-D.: Klimatologie, 3. Auflage, UTB Stuttgart, 472 pp., 2008.

Shindell, D. T., Schmidt, G. A., Mann, M. E, Rind, D., and Waple, A.: Solar Forcing of Regional Climate Change During the Maunder Minimum, Science, 294, 2149-2152, doi:10.1126/science.1064363, 2001.

Sonklar, Edler von Innstaedten, K.: Von den Überschwemmungen, A. Hartleben's Verlag, Wien, Pest, Leipzig, 151 pp., 1883.

Stahleder, H.: Chronik der Stadt München, 3 Bände, Dölling und Galitz Verlag, München, Band 1: 696 pp., Band 2: 807 pp., Band 3: 680 pp., 1995-2005.

Sturm, K., Glaser, R., Jacobeit, J., Deutsch, M., Brázdil, R., Pfister, C., Luterbacher, J., and Wanner, H.: Hochwasser in Mitteleuropa seit 1500 und ihre Beziehung zur atmosphärischen Zirkulation, Petermanns Geographische Mitteilungen, 145, 14-27, 2001.

Usoskin, I. G., Schüssler, M., Solanki, S. K., and Mursula, K.: Solar activity over the last 1150 years: does it correlate with climate? Proceedings of the 13th Cambridge Workshop on Cool Stars, Stellar Systems and the Sun, held on 5-9 July 2004 in Hamburg, Germany, edited by: Favata, F., Hussain, G. A. J., and Battrick, B., ESA SP-560, European Space Agency, 2005, p. 19, 2004. van Bebber, W. J.: Die Zugstraßen der barometrischen Minima, Meteor. Z., 361-366, 1891.

von Zillner, F.: Geschichte der Stadt Salzburg, Druck von J. Dellache, Salzburg, 456 pp., 1885.

Wanner, H., Gyalistras, D., Luterbacher, J., Rickli, R., Salvisberg, E., and Schmutz, Ch. Klimawandel im Schweizer Alpenraum, 285 pp., 2000.

Weikinn, C.: Quellentexte zur Witterungsgeschichte Europas von der Zeitenwende bis zum Jahre 1850 - Band I, Akademieverlag, Berlin, 531 pp., 1958.

Weikinn, C.: Quellentexte zur Witterungsgeschichte Europas von der Zeitenwende bis zum Jahre 1850 - Band II, Akademieverlag, Berlin, 486 pp., 1960.

Weikinn, C.: Quellentexte zur Witterungsgeschichte Europas von der Zeitenwende bis zum Jahre 1850 - Band III, Akademieverlag, Berlin, 586 pp., 1961.

Weikinn, C.: Quellentexte zur Witterungsgeschichte Europas von der Zeitenwende bis zum Jahre 1850, - Band IV, Akademieverlag, Berlin, 381 pp., 1963.

Werner, P. C.: Zur Berücksichtigung der Persistenz in meteorologischen Zeitreihen, PIK Report No. 75, Angewandte Statistik, edited by: Gerstengarbe, F.-W., Potsdam Institute for Climate Impact Research, 43-54, 2002.

Wetter, O., Pfister, C., Weingartner, R., Luterbacher, J., Reist, T., and Trösch, J.: The largest floods in the high Rhine basin since 1268 assessed from documentary and instrumental evidence, Hydrol. Sci. J. 56, 733-758, 2011. 